\title{
In-human Immortality - a Handful Reflections on the Idea of Eternity in the Poetry of Zbigniew Herbert ${ }^{1}$
}

\begin{abstract}
This article is an attempt at a philosophical reconstruction of the idea of eternal life in the poetry of Zbigniew Herbert. The author sets out to discuss the difficulties connected with the ideas of both heavenly (transcendent) eternity, which posits a new mode of existence, and earthly (immanent) everlastingness, based on immortal fame or instants of eternity intermittently available to humans (in other words, a momentary cessation of the awareness of the passage of time). An example of heavenly eternity is the immortality of the soul or the resurrection of the body; according to Herbert, both possibilities signify a radically novel (perfect and infinite) mode of existence, which is totally alien to human (imperfect and finite) nature. This is why man does not desire an eternity of this kind, as it would entail a transformation of his nature into a different, non-human (divine, angelic) being. A paradigmatic example of earthly eternity can be found in profound experiences (such as aesthetic contemplation of beauty), when the contemplating subject loses the consciousness of the destructive power of time, or even of his own eventual demise, deluding himself for a moment that his being is everlasting. Herbert seems to embrace a third way, which is the way of the sceptics, who do not believe in either kind of eternity, consequently living in a state of permanent suspension between the two other ways.
\end{abstract}

Keywords: Zbigniew Herbert, philosophy, poetry, death, immortality, eternal life

Interpreting Herbert's poetry is a perilous task for the philosopher since speculative instruments of philosophy are ill-equipped to deal with the artistic finesses of verse. Moreover, the seemingly obvious philosophical associations (for instance the figure of Mr. Cogito), which may easily lead to erroneous readings and interpretative misconstruals, are another obstacle. A case in point is the poem "Mr. Cogito Tells of the Temptation of Spinoza." 2 Although it offers

${ }^{1}$ Originally published in Konteksty Kultury 2018, vol. 15, no. 1 (the Polish title: "Nie-ludzka nieśmiertelność - kilka filozoficznych uwag na temat idei wieczności w poezji Zbigniewa Herberta”).

2 All English quotations of Herbert's poetry come from: Zbigniew Herbert. The Collected Poems 1956-1998, trans. A. Valles, London 2014. 
accurate portraits of Erasmus, Descartes, and Spinoza, its meaning can by no means be reduced to such historical references. ${ }^{3}$

Another difficulty is the presence of irony, which is evident everywhere in Herbert's work, and, needless to say, he knew how to use it as scathingly as Socrates himself. ${ }^{4}$ In the hands of the poet, it often transformed itself into mockery, driven by a sense of moral indignation. One example is the poem "What Mr. Cogito Thinks of Hell," which is a description of artists presided over by Beelzebub; they have agreed to create art in return for a comfortable life. Irony also allows Herbert to take pity on the limitations of the human mind or the crudity of our judgments of God ("Mr. Cogito's Reflections on Redemption"). Unlike its Socratic counterpart, however, Herbert's irony is no mask, since the Polish poet candidly admits to ignorance. Well cognizant of the fact that everyone, including poets and philosophers, cannot help but be trapped in the cave of fictitious imaginings, Herbert is forgiving when it comes to human weakness, from which neither the financially shrewd Descartes, nor the crafty Erasmus, nor even Spinoza, with his hope of reaching God with the aid of intellect, were quite free; perhaps that is why the poet's irony can also be used as an instrument of compassion ("Kant. Last Days"). ${ }^{5}$

While analysing Herbert's poetry, one must not forget Herbert's censure of speculative thinkers, with their hopes of grasping the secret of being by means of a definition. These dialectical impostors, armed with "a few flailing concepts," 6 and "syntax devoid of the beauty of the subjunctive" ("The Power of Taste"), are

${ }^{3}$ In fact, Erasmus also took good care of his profits, while Descartes failed to take a royal scholarship; at the same time, he exhibited remarkable presence of mind in the legal actions taken against him in the Netherlands. For all these inaccuracies, the portraits of the philosophers painted by Herbert are accurate. It does not really matter whether Herbert borrowed them from Kazimierz Brandys's Rynek. Wspomnienia z teraźniejszości, or whether both writers found them in another source, Herbert's depiction of Spinosa is superior to that of Brandys. See: R. Nycz, “'Niepewna jasność' tekstu i 'wierność interpretacji.' Wokół wiersza Zbigniewa Herberta 'Pan Cogito opowiada o kuszeniu Spinozy," Teksty Drugie 2000, no. 3, pp. 136-138.

${ }^{4}$ Irony, of which Herbert was a consummate master, is often considered to be the hallmark of his poetry. See: S. Barańczak, Uciekinier z Utopii. O poezji Zbigniewa Herberta, Londyn 1984, p. 73. The book has been translated into English: S. Barańczak, A Fugitive from Utopia: The Poetry of Zbigniew Herbert, Cambridge (Massachusetts) 1987 [translator's note].

5 The poem levels critique at both the Enlightenment idea of benevolent nature, and the idea of Providence. It is ironic that the fate of the old philosopher, who became a spectre, contradicts his own theory - not only the notion that both man and nature are rational but also the impossibility of metaphysics. The text can also be construed in the spirit of deprecatory pictures of Immanuel Kant, which, thanks to Heinrich Heine, became legendary. It is important to remember, however, that some of Heine's statements are not true. See: O. Höffe, Immanuel Kant, trans. A.M. Kaniowski, Warszawa 2003, p. 40.

${ }^{6}$ This term refers not only to Marxists but also to dogmatic materialists who believe they have discovered the Absolute. In another poem ("To Henryk Elzenberg on the Centennial of His Birth") Herbert makes use of the category of "think[ing] with a hammer"; while its derogatory connotations are obvious, it is worth bearing in mind that a similar metaphor was employed by Friedrich Nietzsche, who saw it as something positive. Authentic thinking is like the hammer of Jehovah that breaks a rock in pieces $(\mathrm{Jr} 23,28)$, since it demolishes conventional 
busy concocting absurd visions of social stability, such as Communism or the Positivist "Religion of Humanity," which might imply "that all philosophy/ is superfluous/ and even harmful" ("The Cat Sat on the Mat. In Defense of Illiteracy"). That is why the poet cautions philosophers against implementing their ideas into reality. ${ }^{7}$ Their ability to reduce the diversity of reality to a set of simple formulas allows the philosophers to think that they have found the secret of the universe. A facetious description of such "overproduction of ideas" is the portrait of a thinker who has discovered an infinity so immense that in "three or four/ seasons of infinity/ (...) it will outgrow/ even his head"; his efforts are crowned with the word "existence," which is "hard and colorless," thus reducing the whole world to the status of appearance ("The Cultivation of Philosophy"). ${ }^{8}$ Alas, having discovered the mystery, he can neither weep nor laugh, for "existence" is a stranger to emotion. Exposing such misguided pursuits is continued in the poem To Marcus Aurelius, where the thinker's "philosophical Latin" knows neither the cry of fear nor how to dry tears ("To Marcus Aurelius"). ${ }^{10}$

conceptual schemes. Thinking with a hammer may also bring to mind the work of a sculptor who carves a block of stone into the desired shape.

7 His opinion of some poets and theologians was similarly critical: ,one shudders to think/ what the art of reading can do/ when it is let loose/ the art of writing/ wary of the claim/ that all came from water/ or all came from fire/ but not print/ prodding with a pointed feather/ in texts// and thus arise/ all the time/ pathetic new/ treatises/ papal bulls/ retractions/ stakes" (Is There Anything Else I Can Do for You Sir") For some reason, Alissa Valles omitted to translate this part of the poem, so I give these lines in my translation [translator's note].

${ }^{8}$ Equally ironic are the following verses of an untitled poem beginning with the line "An hourglass bursts": "on an avenue of wise dialogues/ the philosophers are wandering/ with the neat steps of surveyors/ confusing the absolute counting." Herbert's scepticism towards the term "being" stems from the fact that the poet is more likely to see a multitude of separate things rather than the abstract commonalities they share. "In his world, being has disintegrated into a collection of disparate objects and they are all he cares about." K. Dybciak, Gry i katastrofy, Warszawa 1980, p. 153.

${ }^{9}$ It might seem at first that Herbert made a mistake, as Marcus Aurelius' Meditations are written in Greek; in Adam Zagajewski's account, having discovered the error, the poet joked about it. See: A. Zagajewski, "Niejasne przesłanie" [in:] Poeci czytaja Herberta, ed. A. Franaszek, Kraków 2009, pp. 169-170. The matter is more complicated than that because Herbert declined to make any corrections in subsequent editions. The rationale behind it was most probably the fact that he wanted to retain the word "Latin" and its rhyme with "begin" and to avoid difficulties which might arise if he tried to replace "your Latin" with "your Greek." It is far more likely that the reference to the Latin of philosophy which knows no fear was meant as a description of the Roman model of culture with its ethos of fearlessness. This is partly borne out by the fact that Roman stoicism was more radical than its Greek counterpart (at least in its imperative of indifference to suffering and death). One of the reasons for that was a pronounced epistemological inclination of Greek stoicism, while the stoics of Rome laid greater emphasis on practical matters. Moreover, in the poem, Marcus Aurelius is elevated to the status of a symbol of the Latin culture of Rome, with its elitist ethos of soldier and ruler, embodied in a valiant man, who takes all vicissitudes in his stride. "Philosophical Latin" does not have to refer to the language of Aurelius' Meditations but rather to a particular modus of thinking which leaves no room for fear, to say nothing of "defenseless tears."

${ }^{10}$ The poem successfully recreates the spirit of Meditations, which is not a synopsis of philosophical doctrine but an expression of existential struggle, resilient to the rigorous ideals of 
When reflecting on Herbert's poetry, it is also important to remember that, despite his university education in philosophy under the guidance of prof. Henryk Elzenberg, he decided to become a poet rather than a philosopher. Perhaps one of the reasons behind that decision was the fact that, unlike philosophy, which deals mostly in abstract ideas, poetry accentuates the concreteness of existence, for instance by imitating songs of birds and dreams of stones ("A Tale"). Although the language of poetry is not perfect ("I Would Like to Describe"), it can reveal the diversity of the world. The philosopher has no such parlance at hand to assist him; consequently, the danger arises that when writing about Herbert's poetry, he may end up performing a travesty of the miracle at Cana by turning the wine of verse into the water of words. ${ }^{11}$ This danger is very real, as Herbert possessed an extraordinary gift for translating complex ideas and elaborate philosophical arguments into evocative poetic images. ${ }^{12}$ In the context of the life to come, a good example thereof is the poem "At the Gate of the Valley," whose contents is likely to be obscured or trivialised, rather than enhanced, through application of philosophical paraphrase. Such difficulties notwithstanding, Herbert was aware of important commonalities between philosophy and poetry. ${ }^{13}$ In a letter to prof. Elzenberg, he confessed that he felt an aversion towards abstract academic philosophy, while at the same time he was drawn to philosophy of existence, which consists of experiencing and inhabiting existential questions concerning the meaning of life, suffering, and death. ${ }^{14}$ The present article, which attempts to examine the issue of meaningfulness, coherence, and attractiveness of eternal life (immortality), ${ }^{15}$ is related to the latter understanding of the nature of philosophy as instantiated in Herbert's poetry. I would like to begin by outlining the context, then I will go on

stoicism. Julian Kornhauser reads it as both a description of the trauma of WWII and an outline of poetic program. See: J. Kornhauser, “'Struna światła' - między ocaleniem a niepokojem,” Teksty Drugie 2000, no. 3, p. 22.

${ }^{11}$ I have borrowed this comparison from a short text by Roman Brandstaetter entitled Cud księdza Michata; its main protagonist publishes his religious meditations every week, thus diluting the wine of the Gospel into the water of commentary. See: R. Brandstaetter, Bardzo krótkie i nieco dtuższe opowieści, Poznań 1984, p.108.

12 And the poem Why the Classics gives a superb synopsis of Thucydides' Peloponnesian War. See: A. Sosnowski, "Epizod” [in:] Poeci czytaja Herberta, op. cit., pp. 73-74.

13 One of them was the aesthetic dimension of the language of philosophy. According to Konstanty A. Jeleński, Herbert intended to write an article on this issue, but his plans never materialised. See: P. Siemaszko, "Piękno jako odpowiedź. O malarskich fascynacjach Zbigniewa Herberta," Ethos 2000, no. 4, pp. 183, 9.

${ }^{14}$ See: M.K. Siwiec, "Zbigniew Herbert - twórca i źródło. Droga do źródła i źródło w wierszu 'Ścieżka,'” Filo-Sofija 2013, no. 3, p. 107. In a letter to Jerzy Zawieyski Herbert employs the category of "thinking dramatically"; Søren Kierkegaard was, in Herbert's eyes, a philosopher who thought dramatically. See: J. Kopciński, Nastuchiwanie. Sztuki na gtosy Zbigniewa Herberta, Warszawa 2008, p. 12.

15 I use these terms interchangeably to denote a kind of existence from which death has been banished. 
to describe two models of everlasting life (heavenly eternity and earthly eternity), and finally I will discuss the poet's skeptical approach to the problem. Let me also add that the methodology employed in this essay is synchronic rather than diachronic, which will allow for a reconstruction of the philosophical idea of eternity in Herbert's oeuvre. The main aim of this article is to outline the possibility of finding a viable solution to the problem of eternity, which can be seen more readily in his poetry rather than in historically or philologically accurate reenactment of shifts and modifications of his artistic craftsmanship or Weltanschauung. That is why I will refrain from discussing the ideological evolution in the poet's viewpoint by collating poems written in different periods of his career. Examples of relevant texts include such poems as, on the one hand, "Mr. Cogito Observes a Deceased Friend," with its philosophical (stoical) meditation, or "The Paradise of the Theologians," which is essentially a parody of theological treatise; on the other hand, we have such poems as "To the Fallen Poets," brimming with bitterness and anger, or the late poem "Breviary," beginning with the words "Lord, I know my days are numbered" clearly an intimate account of a struggle with destiny, in which one can almost hear the broken voice of a dying man.

\section{Death and Life Everlasting}

The question of eternal life often appears in the context of the experience of evil and injustice. In this life, the virtuous suffer unmerited agonies, while the wicked thrive; it is therefore necessary to postulate a posthumous existence, where all sorrows will be made joy and all evils punished. In the context of theism, this problem acquires an additional aspect linked to attempts at exonerating God of the existence of evil in the world. If every man is guaranteed to experience the plenitude of life after death as a reward for earthly anguish, one may suppose that the evil we suffer today will be redeemed. This problem does not appear in Herbert's poetry; however aware of the innumerable villainies of history he might have been, the poet never thought of immortality as an instrument of atoning for evil. His anthropological vantage was closer to naturalism; he regarded man as a biological, conscious, and vulnerable creature. As a result, he saw pain as an integral element of existence, and believed there was no need to diabolise it ("Mr. Cogito Reflects on Suffering").

Unlike Czesław Miłosz or Witold Gombrowicz, who both refused to accept the cruelty of nature (and saw survival of the fittest as nearly devilish ${ }^{16}$ ), Herbert

16 Łukasz Tischner offers many a penetrating insight on the problem of evil, including natural evil, in two excellent books: Sekrety manichejskich trucizn. Mitosz wobec zta (Kraków 2001) and Gombrowicza milczenie o Bogu (Kraków 2013). According to Miłosz, evil present in 
reflected on this question in less dramatic terms. Even if there really is a devil, he is equipped with human characteristics, in particular with an indifference to good and evil ("A Devil"). Admittedly, he may sometimes be indolent and sluggish, but also stubborn, and that is why "he survives everyone" ("Native Devil"). That does not mean that the evil which is banal and "folksy" ceases to be evil, ${ }^{17}$ but Herbert does not deem it necessary to grapple with it with the aid of "theodicial" speculations, which are as ingenious as they are ineffective. ${ }^{18} \mathrm{He}$ was even more contemptuous of utopias, which glorify atrocities perpetrated in the name of some fictitious good in the future. ${ }^{19}$

$\mathrm{He}$ also approaches the question of eternal life from the perspective of human nature; man refuses to come to terms with the fact of mortality because he finds that it is impossible for him to realize all of his desires, which include discovering the whole of truth and achieving happiness, in this life. Although such an anthropological angle appeals to Herbert, what he really wants to investigate is not so much the human desire for immortality as the appeal of specific images of eternity as a cure for death.

A recurrent image of death in Herbert's poetry shows, on the one hand, the atrocities of tyrants, who have no hesitation in sending their subjects to be slaughtered, and, on the other, the sacrifices of the innocent, who dared to challenge authority. The poet seems to go so far as to suggest that murder in the name of insane ideas, which even the despots themselves hardly believe in, is the main substance of history ("The Rain"). ${ }^{20}$ Those who dare to resist will be trodden into the mud, which will be witnessed only by a silent guard ("Answer"). After all, as Herbert sarcastically points out, wars are always fought

nature is an argument against theism; Gombrowicz in turn believes that it may even be an argument for Satan's existence.

17 According to Barańczak, Herbert belittles the problem of evil, which is corroborated by his conviction that Greek myths cannot be transposed into today's world, as this would strip them of their tragic dimension. See: S. Barańczak, op. cit., p. 117. At the same time, things become more complicated if we include the poem "Oaks" from the collection "Elegy for the Departure," where reason's powerlessness in the face of evil as well as anger and rebellion against God are manifest (and it hardly matters whether one chooses to see Him as the creator of nature of the author of history).

${ }_{18}$ Ryszard Przybylski believes that Herbert rejects all theodicies, including its Christian variety, since he deems them as perilous as social utopias. See: S. Barańczak, op. cit., pp. 14-15. Also, the above-mentioned poem "Oaks" seems to rule out theodicy. On the one hand, one cannot exclude the possibility that the creator of the world is "a demiurge of contemptible statistics/ playing with dice always fixed in his favor"; on the other, our pathetic quests are always lost in the abyss of mystery, unable to overcome the despair which gave rise to them.

19 Every utopia starts with visions of an ideal world and ends with concentration camps. See: ibid., p. 127.

${ }^{20}$ The main protagonist of the poem is a man who has become unhinged as a result of comparing himself to Roland or Hannibal. But he may also be a compact universal portrait of the soldier, dying on the battlefield of Grunwald or Verdun; this is why the dead Feliksiak is as important as the great heroes of history or mythology. 
over the greatest of causes, such as the colour of the uniform ("Soldier"). ${ }^{21}$ The most tragic thing of all is that people, consumed with primeval thirst for blood, run to the beat of the drums as if they really believed that "death en masse is not so bad" ("Drum Song").

It is particularly hard to accept the heroic death of those who are subsequently "rewarded" with oblivion or derision ("Farewell to September, To the Fallen Poets"). What drove them to sacrifice, however, was not solely their determination to defend values such as liberty, honour, or loyalty, but also a desire for heroism; after all, when all is said and done, even death can become a magnificent spectacle, if only viewed from the appropriate perspective ("The Sacrifice of Iphigenia"). ${ }^{22}$ What this implies is that, at the end of the day, all differences between the perpetrators and the victims are canceled out since "a shallow plain levels/ the veil and the good" ("Baptism").

Considering death in the large scheme of history leads to a situation where even the dread of death assumes a concrete form; to be sure, it may take the shape of metaphysical angst in the face of nothingness ("Oaks," "Mr Cogito's Monster"), but it may also display itself in the mundane feeling of fear at the news that "the place on Długa Street is hot," and a friend needs to be warned ("Our Fear"). After all, it is only too easy to keep people in the state of terror or even to drain them of blood, all the more so when, from the perspective of the universe, five litres of blood are a "negligible sum" ("Mr. Cogito Thinks about Blood"). This aspect of death is important, because Herbert also employs militaristic metaphors in his descriptions of the biological process of dying; after all, the act of dying is a battle fought by two warring parties inside a living organism, each seeking stratagems to outsmart the other ("Stake"). Unlike man-inflicted death, however, natural demise is inscribed in the natural order, which cannot be changed ("Mr. Cogito on a Set Topic: 'Friends Depart"). It lacks any metaphysical horror, instead showing a consciousness drawing to its natural end ("sight turns away and hearing fails" in "Common Death"), occasioned by a trivial cause: "not fate not lightning but an insect." Nevertheless, this naturalistic account may be misleading; even if death is no sinister force

${ }^{21}$ Michel de Montaigne in his Essays often traces the beginning of military conflicts to differences in clothes, dialect or geographical location. Herbert's poetry, however, makes no reference to the French philosopher, at least not explicitly. It seems worthwhile to investigate potential affinities between Montaigne's and Herbert's respective brands of scepticism.

${ }^{22}$ Describing Iphigenia's death as magnificent in the final sentence of the lyrical prose "The Sacrifice of Iphigenia" ("The view is magnificent, if you call to your aid the appropriate perspective") also carries ironic undertones, as Herbert is exposing the abusive nature of rites involving human sacrifices to gods. Likewise, heroic death in defence of faith, country or nation can be seen in the same light. Although it is usually remembered as heroic and something to emulate, it may also prove cruel and pointless, just like the death of Iphigenia. This reading is supported by accusatory poems denouncing those who have the temerity to take advantage of heroic deaths or cynically call others to sacrifice ("Farewell to September," "Buttons"). 
from the netherworld, it still remains unfathomable. The deceased friend was breathing just a while ago, while Mr. Cogito adjusted his pillows; however, after stepping out to smoke a cigarette, Mr. Cogito returns to the room to find that "his friend was gone/ in his place/ lay something else/ with its head tilted/ its eyes bulging" ("Mr. Cogito Observes a Deceased Friend"). This picture implies that even if Mr. Cogito had kept continuous vigil at the bedside, he would not have been able to notice the physical change that resulted in his friend's becoming an inanimate object. Though, undeniably, death falls into the category of observable processes of biology, by the same token these processes prevent us from reaching down to its deepest mystery. At the level of physical events, connected with the immobility of the body which has ceased to breathe and respond to stimuli, it is impossible to grasp the nothingness which has just insinuated itself into the world. The poem suggests that death has a complex structure, and only one of its outer layers (the sensorially perceptible actions of the dying person) is available to us; the metaphysical component remains hidden. Likewise, language, which is both mysterious and complicated, has a similar structure. It may be true that Horace uses the same language as hoodlums, so one had better not rip poetry "from the claws/ of the everyday," but only the poet can discover the most profound depths of the language he shares with hoodlums ("Mr. Cogito. Ars Longa").

An encounter with death is an experience of utter loneliness; even the screams of the mother, who "rends a numb name," is powerless to awaken the dead ("White Eyes"). At the same time, although we find the death of the loved very cruel, it does not necessarily have to be cruel for the dead, as it sets them free from the foes and fardels of living ("Leo's Death"). It is particularly conspicuous in the context of a long, drawn-out dying process when death brings relief, much like sleep or a narcotic ("Breviary I"). Dying is a ghastly experience, as if nature takes pleasure in tormenting those who have been defeated in their struggle for existence ("The Last Attack. To Klaus, Stake").

The fate of the dead person remains veiled to us, and death can be discerned only from the point of view of the living as the final destination of those who have come before us ("Artur"). The deceased may leave behind a few material objects - a pen, a chair, or a desk, on occasion a handful of disciples or a few books, "more lasting than bronze," may remain - but the main question concerns the world he has arrived at rather than the one he has departed from ("To Henryk Elzenberg on the Centennial of His Birth"). In keeping with an irony so characteristic of Herbert, the question seems an ordinary one: "whether I'd get a new apartment" ("A Life from the collection Rovigo"), ${ }^{23}$ and wondering

${ }^{23}$ The poem can be read in the context of nagging quotidian worries of the day (back then purchasing an apartment was nothing short of a miracle), and of "our little stability" of 1960s, when a TV set, a piece of furniture or a Fiat 126p (let alone a new apartment) were for many Poles the ultimate dream. However, an eschatological dimension is also tangible in the poem; 
gravely whether what awaits us after death is "the golden fleece of nothingness" ("The Envoy of Mr. Cogito") or whether we will swell the numbers of angels' choirs, enveloped in "vast mysterious radiance" ("Artur"). One source of hope for immortality may stem from the impossibility of contemplating one's own annihilation, wittily expressed by the poet in the line: "I'm not there I'm not there period a perfect emptiness" ("The End"). But understood in its most literal sense, the statement "I am not" is self-contradicting; to be sure, it is possible to say "I am not in Kraków" (since I happen to be in Szczecin at the moment), but one would have difficulty in conferring internally consistent logic on the sentence "I am not" (in its absolute sense, signifying that I do not exist at all). If I am still able to say, "I am not," it becomes obvious that I am still present as an extant and conscious subject which is in vain trying to think about its absolute non-existence. The impossibility of consistently thinking about the annihilation of one's deepest self has been regarded, through the centuries of philosophical reflection, as a proof of immortality (John Locke, Edmund Husserl). According to this line of reasoning, there will never arise circumstances in which the subject will be able to conclude beyond any doubt that his death was an irrevocable termination of his existence. ${ }^{24}$ Neither will a third party be able to definitely arrive at that conclusion. The mere sight of my dead body cannot produce incontrovertible evidence of my absolute obliteration as a separate thinking subject. A hope for immortality, which consequently arises, is particularly poignant in the case of a sudden death, at the hands of "history's schoolyard bullies" ("Biology Teacher"), a death which at first sight can neither serve nor save anything.

According to the poem "Baptism," two roads are open to us - one leading up, and the other down. The former shoots up towards the angelic perfection of heaven ${ }^{25}$ the latter may mean either the disintegration of the body in the grave, or staying in this world as a beetle ("Biology Teacher"). Another possibility is to gain posthumous fame, which will live on in the memory of future generations ("Forest of Arden"). One possibility is to achieve life everlasting

interestingly, without negating the mundane references of the poem, it actually complements them: "Like others I wanted to know what I'd be after death/ whether I'd get a new apartment if life had meaning." It is also possible to see in these lines how attached people are to their terrestrial existence, and consequently, pattern the images of the life to come on this one.

${ }^{24}$ Freud believed that the impossibility of thinking one's annihilation proves that immortality, of which we have intuitive (instinctive) understanding, is a more fundamental notion than death, which has to be learnt from experience by seeing living creatures die.

${ }^{25}$ According to Jadwiga Puzynina's calculations, the word "heaven" appears as many as seventy-five times in Herbert's work, but only three times as denoting the seat of God and the elect ("Biology Teacher," "Shore," and "The Nepenthes Family"). In all the other poems it is used metaphorically. See: J. Puzynina, "Niebo Herberta," Ethos 2000, no. 4, pp. 71-72. I am far from disputing these conclusions, but in this text, I will use the term "heaven" not only to signify the habitat of the saved but also a specific form of existing after death. References to heaven thus understood are numerous in Herbert's poetry. 
in the world to come, while the other is to remain within the confines of this world, with the two options of either perpetuating one's existence or disappearing into nothingness.

\section{Heaven}

The strand of Platonic idealism, whose presence has been tangible down the centuries of European philosophy, identifies man with an immortal soul which is liberated from the confines of the material world at the moment of death and subsequently exists in its divine essence. The idea of immortality has had a strong presence in Christianity, becoming one of the main dogmas of the Catholic Church. ${ }^{26}$ Although it is linked to a belief in the resurrection of the body, as expressed in the Apostles' Creed and Nicene Creed, in the resurrected body, based on the descriptions of Jesus' epiphany, the spiritual traits outnumber the physical ones. ${ }^{27}$ If this is so, contrary to a well-known proposition formulated by Oscar Cullmann, there is no great difference between the immortal soul and the resurrected body since both are based on the transfiguration of a mortal being into one that is immortal. Herbert also ignores this distinction, arguing that it is impossible to consistently separate the soul from the body, as we cannot help relying on sense-based expressions even in our depictions of an immortal soul ("Report from Paradise"). ${ }^{28}$ What brings the two models together is more important than what sets them apart; the proper distinction ought to be made not between the immortal soul and the resurrected body, but between the human and the angelic (divine), the earthly and the celestial.

26 The dogma was promulgated in the year 1513 by Leon X, one of the most ardent Platonists in the history of Christianity. See: W. Sady, Dzieje religii, filozofii i nauki. Od Pico della Mirandoli do Miguela Serveta, Kęty 2013, p. 26. The chief rationale behind the dogma was the desire to counter the influences of Aristotelian philosophy, as its proponents frequently questioned the possibility of finding rational proof for the immortality of individual souls.

27 See: M. Szram, Ciato zmartwychwstate w myśli patrystycznej przetomu II i III wieku, Lublin 2010; Z. Kijas, Niebo, czyściec, piekto. W domu Ojca, dla kogo, w oddaleniu, Kraków 2010.

${ }^{28}$ The construction of a perfect world described in this poem may refer both to the idea of building a communist society (including the inevitable deviations from the doctrine brought about by real life) and a critique of the idea of creation of man by God and purely spiritual visions of resurrection. The soul cannot help but be fastened to "a drop of fat a thread of muscle," while "the heavenly proletarians/ awkwardly under their arms they carry their wings like violins." Furthermore, "not many behold God/ he is only for those of 100 per cent pneuma." These two lines may be taken to refer to those excluded from celestial bliss (especially in the context of the line "only John foresaw it: you will be resurrected in the flesh") but also to the structure of a communist state, where only the most loyal, and free from the faults of bourgeois mentality, citizens are allowed to appear before the highest authorities. 
If we accept the possibility of heaven, there immediately arises a question concerning the ontological continuity of the person who walked and lived out their life in this world. Will he or she be the same person? A variety of solutions have been put forward; some have looked for the foundations of identity in the existence of an individual soul, which remains untouched by the process of physical decay (Plato), others have pointed to the soul's ability to adjust itself to a specific body, with which it will be conjoined once again in the life to come (Thomas of Aquinas), and others still have found it in the notion of divine omnipotence; after all, it is much easier to reanimate a dead man than to create him anew (Blaise Pascal). There is no mention of any of these ideas in Herbert's poetry, and the reason for that is not the poet's scepticism toward philosophical speculation as such, but his engagement with a more fundamental issue - whether the transmutation of a finite (human, earthly) life into an infinite (angelic, divine) existence will be something good for man, something to be desired. Herbert answers in the negative because a transformation of people into perfect beings would amount to a destruction of their nature. Stripped of the physical body, man would be an entirely new entity, and not the being he was in his earthly existence. To be sure, this new creature would have a greater degree of perfection, but he or she would merely be a copy of the original, analogous to the frescoes at Heraklion, where the only surviving fragments of the originals are "cracked bulges of indefinite color on the surfaces"; everything else is "reconstruction, guesswork, fantasy (...), as if someone had filled out found fragments of an ancient poem with his own words." 29 The paradise of the saved would be just like that; they would be angels rather than human beings.

Herbert is convinced that an immortality of this kind is inhuman, so Mr. Cogito resolves to defend himself against it. Even when they pack him off to a purgatorial training for candidates for paradise (the aim of which is to eradicate earthly habits), he will beg to be spared the pleasures of heaven; he will ask the recruiting commission to let him return to "an overgrown path/ on the shore of a white sea/ to the cave of the beginning" ("Mr. Cogito's Eschatological Premonitions"). ${ }^{30}$ This is further confirmed by Herbert's image of Judgment Day with "the whole lowing two-legged herd" ("At the Gate of the Valley"), reminiscent of a concentration camp, where people are stripped of

${ }^{29}$ Z. Herbert, "Labyrinth on the Sea" [in:] The Collected Prose, 1948-1998, ed. A. Valles, trans. M. March, J. Anders, B. Carpenter, A. Valles, New York 2010.

${ }^{30}$ The poem can be interpreted in a less literal manner as a metaphor for building a totalitarian system which is supposed to be heaven on earth. Herbert firmly believed that no utopia can be benevolent; on the contrary, it is the builders of utopias that coerce man into their heavenly (or one should say infernal) projects. At the same time, a literal reading which takes its clue from the tile is most certainly correct. Commonalities between social utopias and religious images of paradise are not limited to the use of sacral categories by the reformers; eschatological visions of many religions can also be extremely cruel. 
their individuality. ${ }^{31}$ The recruiting commission "eradicates the senses left/ to candidates for heaven," which only serves to enhance Mr. Cogito's fear "that he is unfit/ for heavenly/ service." If, however, he is indeed transformed into an angel, "a tiny withered flame that walks along the paths of winds" ("Anything Rather than an Angel"), he is going to rebel since, to Mr. Cogito, heaven would mean the loss of everything he most cherishes.

As an angel, with far too much free time on his hands, Mr. Cogito will experience monotony and boredom, like "a tuberculosis patient" or "an emperor in banishment" ("Eschatological Premonitions of Mr. Cogito"). These descriptions raise the problem of the tedium of eternity, which has been discussed both by philosophers and poets; they believe that life everlasting, which consists in incessant experience of the same thoughts or repeated performance of the same actions, would have to lead to a desire for death. ${ }^{32}$ Herbert goes even further, as he ascribes inertia and "mighty yawns" even to the immortal gods, who enjoy the plenitude of living ("Mr. Cogito and Longevity"). Although it would be possible to see such opinions as denigrating to the deities, ${ }^{33}$ they also question the idea of salvation understood as worshipping the Almighty with "the murmur of two-dimensional choirs" ("Anything Rather Than an Angel"). In this way, the poet expresses his fear of existence which is not fit for man. After all, we could be blinded by the whole truth since every act of perception depends on assuming a certain viewpoint, but in heaven truth would be known in its entirety, with no meditating perspective ("The Paradise of the Theologians"). What is right for angels may prove fatal to mortal beings. ${ }^{34}$

It is equally hard to renounce the body ("Mr. Cogito's Eschatological Premonitions"); even though we feel limited by it ("The Hygiene of the Soul"), the body remains our only link to the world. Man is hardly an incorporeal soul soaring towards the heavens like Icarus, but rather "living plasma" with "two arms to brace the head," "two legs hasty in an escape," "able to breathe," "able to come by food," and "able to pass life under a prison wall" ("Substance"). Reduced to an angel, Mr. Cogito would be similar to the dead lying in their graves, with mouths filled with sand, unable to make a sound. His immortality

31 The terror of "heavenly recruitment" is further augmented by the language of the poem, which is redolent of the voice of a radio reporter commentating a sporting event or a May First march. See: S. Barańczak, op. cit., p. 101.

32 See: B. Williams, "The Macropulos Case: Reflections on the Tedium of Immortality" [in:] Problems of the Self: Philosophical Papers 1956-1972, Cambridge 1973, pp. 82-100; J.L. Borges, "Nieśmiertelność," trans. D. Walasek-Elbanowska, Literatura na Świecie 1988, no. 12, pp. 4554; J.L. Borges, "Nieśmiertelny," trans. M. Potok-Nycz [in:] idem, Alef, trans. Z. Chądzyńska, M. Potok-Nycz, Warszawa 2003, pp. 5-27.

33 See: S. Barańczak, op. cit., p. 69.

${ }^{34}$ Perception is based on the principle of selection of data; but for its operations, it would degenerate into a chaotic stream of experiences precluding the possibility of discerning any specific object. Memory works in a similar fashion; if it were not selective, it would be completely useless, or even lethal, as illustrated by Borges in the story "Funes the Memorius." 
would be as fictitious as the existence of a well-conserved skeleton sold to the medical academy ("To My Bones").

Mr. Cogito is even more dismayed at the loneliness of the elect who are admitted into heaven, each one alone. The Last Judgment is torn with the searing "cry of mothers from whom children are taken" ("At the Gate of the Valley"); one can also notice a despairing old woman, who "carries/ the corpse of a canary," because "he was so nice" and "understood everything," or a lumberjack clasping an axe, which nourished him on earth ("At the Gate of the Valley"). The poet's eternity will be every bit as depressing, "without travel/ friends/ books" or "a pen/ ink/ parchment" ("Mr. Cogito's Eschatological Premonitions"). ${ }^{35}$ Some may still delude themselves that they will somehow manage to hide "fragments of letters ribbons clippings of hair/ and photographs" from the guards, but smuggling even a small fragment of earthly reality into the paradise is strictly forbidden ("At the Gate of the Valley").

This image may be understood as a polemic against Jesus' teaching that "At the resurrection people will neither marry nor be given in marriage; they will be like the angels in heaven" (NIV Mt 22, 30). ${ }^{36}$ The poet defiantly claims that even in heaven there are values more important than contemplation of God, ${ }^{37}$ since man is not destined for the delights of paradise, but for life on earth; if the creator has really destined us for eternity, it must be a kind of eternity which is in proportion to our nature. Like Rainer Maria Rilke, who asked God in The Book of Hours to give each person his own personal death which moves out of the same life he lived, Herbert asks God to give each person their own eternity. It is much better to "enter rock, wood, water, the cracks of a gate" ("Anything Rather Than an Angel") than heaven with its deadness of perfection ${ }^{38}$; it is right that we should remain as "the creaking of a floor," trodden by those who are close to us, instead of turning into "shrilly transparent perfection" ("Anything Rather Than an Angel"). Although in heaven we might be strolling along the alleys of manicured trees past "the stony symbols of virtues, the pure qualities, the ideas of objects and many other completely unimaginable things" ("The Paradise of the Theologians"), such a world would not be human. ${ }^{39}$ This message is strengthened by the range of poetic devices used by Herbert; after all, whiteness and brightness ${ }^{40}$ are symbolic of perfection in his work; this corresponds to the biblical symbolism of paradise. ${ }^{41} \mathrm{But}$

${ }^{35}$ Little wonder that even as a child Mr. Cogito found the idea of immortality terrifying (“Mr Cogito and Longevity").

36 All biblical quotes come from New International Version.

37 Bolesław Leśmian's poem Urszula Kochanowska has a similar resonance.

38 See: S. Barańczak, op. cit., pp. 52, 62-63.

39 Ibid., p. 61.

40 Ibid., pp. 49-50.

${ }^{41}$ The saved are wearing white robes, having washed them in the blood of the Lamb (Rev. 7, 9-14). 
since whiteness is also a symbol of inertia, death, and silence, ${ }^{42}$ the true face of man as an imperfect and broken creature is revealed by Herbert's favourite colour - grey. ${ }^{43}$ This implies that Mr. Cogito inhabits neither the earthly Arcadia of the utopists nor the heavenly paradise of the theologians. ${ }^{44}$ Even if he tried to reenact the feat of Icarus (who failed to understand that the wings are only metaphorical), he would fall to his death ("Daedalus and Icarus"), since man is fastened to the ground. ${ }^{45}$

The way Herbert's depicts heaven undermines the traditional division of people into "those gnashing their teeth" and "those singing psalms" ("At the Gate of the Valley"). If the saved are indeed stripped of everything they once cherished, they experience suffering comparable to that which is inflicted on the damned. Thus heaven is debunked ${ }^{46}$; on the one hand, it is nothing but icy perfection visible in "stony symbols of virtues" ("The Paradise of the Theologians"),${ }^{47}$ and on the other, accounts of paradise can sometimes be too "honeyed" ("Homily"), as preachers sugarcoat reality just like the ornament-makers, decorators, and poets, who care not about the truth, but about superficial comfort, mirth, and joy. This might imply that inferno will be in fact a more appealing form of eternity. Although it is a state of despair (man is ashamed to go outside with bitten lips and shoes falling apart) and futile waiting for salvation (the waiter will never bring a coffee or a lemonade), the lovers can still entertain the illusion that they will always be together, which even the devil chuckling behind the curtain cannot change ("Hell"). ${ }^{48}$ If we are saved each one alone, being in hell

${ }^{42}$ See: S. Barańczak, op. cit., p. 47.

${ }^{43}$ Ibid., pp. 49, 65; K. Dybciak, op. cit., p. 159.

${ }^{44}$ See: S. Barańczak, op. cit., p. 127. Herbert also voices his fear of perfection in the poem In the Studio, where the poet finds fault with the world created by God; its very perfection makes it "impossible to live in." The world created by the painter ("full of error" but also filled with colour) is more friendly than the work of the cosmic watchmaker, constructed according to precise measurements. Consequently, it is hard to agree that Herbert saw man as a creature longing to return to the lost paradise (which is allegedly implied in the poem "The Book" from the collection Rovigo). See: M. Dzień, “Bogowie Herberta," Teksty Drugie 2000, no. 3, p. 166. In spite of this pessimistic interpretation, it is possible to see the moment of expulsion from paradise as our proper birth, a revelation of who we really are.

45 See: S. Barańczak, op. cit., pp. 53, 257. The fate of the priest who is celebrating the mass is similar; he ascends to God up the altar steps; however, this act of transcendence is short-lived as, after climbing "up the first two rungs," the priest "slides back down/ like a fly" ("Last Request"). The poem "Preliminary Investigation of an Angel" carries a far more dramatic charge as Herbert debunks our delusions; the tortured man, who knows very well that he is innocent, still believes that law and justice will prevail, but after a while he is reduced to a bloody scrap of meat.

46 See: S. Barańczak, op. cit., p. 101.

${ }^{47}$ Considering the significance of the figure of stone in Herbert's poetry, it might be interesting to compare such a vision of paradise with Kamienny świat, a collection of stories written by Tadeusz Borowski.

${ }^{48}$ It is also possible to read this text in a more literal fashion as a picture of city life, showing isolated individuals living in overcrowded blocks of flats. 
with others is preferable to being in paradise - alone. In this way, the ethical significance of the afterlife is called into question, as it becomes difficult to see heaven as a reward for the virtuous, and hell as a punishment for the wicked.

Such a conclusion does not mean that Herbert doubted God' mercy ${ }^{49}$; if He indeed prepared heavenly glory for us, it would be petty to suspect him of malicious intent. God's mistake was to offer too much to us, ignoring the inherent limitations of our nature. He may have wanted to give humanity all that is best, but he failed to predict that in this way he would condemn people to suffering. He is like a parent who took away the child's beloved toy because it was old, broken, and dirty, and bought a new one instead, which the child does not want and will not play with. Likewise, the creator fashioned a glamorous palace in heaven, but failed to realize that we feel much better in our humble earthly abode. What He lacks is not mercy but omniscience. From the vantage of classical theism, this would mean that He is not God at all. From the viewpoint of Herbert's poetry, by contrast, the situation is different, as what is the most perfect ("most beautiful") is the object which does not exist ("The Study of the Object"). In this way, the poet ironically undercuts a classical idea of philosophy, most fully formulated by Gottfried Wilhelm Leibniz, which maintains that perfection is the principle of all existence; in fact, the opposite turns out to be true - perfection precludes the possibility of existence. A conclusion of this kind is likely to give hope to Mr. Cogito; since only imperfect things can exist, even heaven itself must have certain imperfections, which will make

49 According to Kopciński, Herbert's doubt about God's mercy comes to the fore in Socrates' monologue in Cave of Philosophers; see: J. Kopciński, op. cit., pp. 203-204. Apparently, the poems "Nail in the Sky" and "Malachovski's Ravine" are other examples of Herbert's disappointment with God, as they show fruitless prayers for divine assistance. See: J. Puzynina, op. cit., pp. 76-79. Also, the metaphor of the star (used as many as forty-nine times) or clouds (employed thirty times) supposedly demonstrates God's indifference. See: ibid., pp. 79, 24. This is part of a broader problem as it touches on the question of the possibility (or rather - impossibility) of believing in God after the Holocaust; in the wake of it, "heaven is talking some foreign tongue" ("To Marcus Aurelius"). See: J. Kornhauser, op. cit., p. 23. At the same time, in an untitled poem dedicated to Barbara Toruńczyk (published in issue 68 of Zeszyty Literackie), Herbert looks at the world through the eyes of a child, which makes God even more responsible for evil, thus ruling out the possibility of forgiving him for the horrors of history. See: M. Cyranowicz, "Herbertowskie inedita," Ethos 2000, no. 4, pp. 219-220. Garbol by contrast believes that Herbert juxtaposes the Christ, as someone close to God, against the inhuman visions of heaven. See: T. Garbol, "Kilka czystych taktów," Ethos 2000, no. 4, p. 95. This reading is rather dubious; Wojciech Bonowicz's commentary on the question of Christ in Herbert's work, based on his analysis of the poem "A Halt," is far more convincing. Although the scenery of the poem seems to hint at the presence of the crucified Christ, there is no mention of the Resurrection, which makes the repast a funeral party (or a meal after a hard day's work of the executioners); as such it is hardly suggestive of the Eucharist. See: W. Bonowicz, "Otwarcie wiersza" [in:] Poeci czytaja Herberta, op. cit., pp. 29-39. Yet another question is whether Herbert himself believed in the Christ; Jan Sochon answers in the affirmative. See: J. Sochoń, "Bóg poety," Ethos 2000, no. 4, pp. 120-125. 
it more tolerable. ${ }^{50}$ Man may adore "lasting things/ things all but immortal" ("Mr. Cogito's Adventures with Music"), but he will choose "earthly measures and judgments." Thus, casting his lot with the idea of paradise as continuation of this world ("Biology Teacher"), he rejects the notion of deification through music; he chooses the way down.

\section{Earth}

Earthly immortality may assume a variety of forms; one of them is pantheistic dissolution in the world. The problem is that immortality of this kind would be synonymous with nothingness ("Lines of a Pantheist") since at the moment of death the individual self disappears while the body disintegrates. Even if this process does not spell the end of existence but only a transfiguration, ${ }^{51}$ man nonetheless becomes reduced to the condition of things ("The Dead"). ${ }^{52}$

Another mode of immortality is reincarnation, which allows hope that it will be possible to meet the dead in the shape of "a beetle clambering/ over a mound of sand" ("Biology Teacher"). This image may be suggestive of a possibility of further incarnations after death (also in non-human creatures), but it may also express hope that immortality (in whatever form it may assume) will be an enhancement of all the values we cherished on this side of the grave. Consequently, an explorer of nature may dream of becoming privy to nature's innermost secrets in the life to come; in this reading, the beetle from the poem "Biology Teacher" is not so much an instance of the reincarnation of a human being into an animal, but a symbol of the posthumous perpetuation of all the values espoused by the dead teacher in this life. If this interpretation is tenable, it may be concluded that even in his time-bound existence, the explorer was granted fleeting moments of eternity, during which he managed to glimpse the secret of living organisms (such as modes of life and conduct of beetles). Such moments of epiphany, familiar both to scholars who chance upon a new discovery and to religious-minded individuals, who enjoy a sense of unity with the object of their worship, as well as to artists discovering beauty, may all suggest that eternity does not begin after death but pervades our earthly existence in instances of overwhelming elation, during which we briefly transcend the awareness of our transience.

${ }^{50}$ Also, in totalitarian systems life is still possible only because they have not yet reached perfection.

51 See: J. Gutorow, “Herbert, pies i gwiazda” [in:] Poeci czytaja Herberta, op. cit., p. 68.

52 I leave to one side the question of whether, and to what extent, things themselves are capable of feelings in the world of Herbert's poetry; after all, in his work man is always reduced to "a part of the scenery, alongside stones, grass, trees, animals big and small," ibid., p. 67. 
Examples of such instants of eternity (arrested time) are epiphanies generated by feelings of ecstasy or sadness, or revelation of transcendence available in an act of contemplation..$^{53}$ As Herbert argues in "A Parable of King Midas," man is a creature made of "blood and illusion," capable of deriving delight from beauty. That is also confirmed by the painter who "sets down the life of shadows" "54; everyone who looks at them will experience illumination - an instant of eternity. Although the painter is mortal and the vase is brittle, beauty seems eternal.

For all such optimism, Herbert insists that no one is saved by art ("Isadora Duncan"), ${ }^{55}$ while the quest for beauty itself ends in disaster. Although the poet may try to create a new word "in the table's wilderness," at the end of the day he must concede that "the ascension/ failed" ("Writing"). ${ }^{56}$ Likewise, his built-on-ink oeuvre, cannot be eternal ("Nothing Special"); at the same time, his poems are records of moments which cannot be expunged by the passage of time or death..$^{57}$ In the spirit of Marcus Aurelius' Meditations, Herbert suggests that he who has experienced an instant of eternity in this life does not need to dream of further existence in a different place. Just like a single day of life contains in itself all of life's contents (hunger, satiety, sadness, joy, suffering, relief, hope, despair, fear, solace), a momentary illusion of manumission from time's manacles may yield an experience of eternity. What really makes people unhappy is not the fact that there is no other life, but that temporal instants of eternity are more often connected with pain than with pleasure; after all, alongside his intellect, Mr. Cogito also has a body, which is capable of feeling pain and fear. In such circumstances, true happiness consists in the state of being purged of illusion ("Farewell"). Certainly, even on our deathbed we may still succumb to the hope "that we will return" ("Prayer of Old Men"), but return will be possible only in the memories of those who survive us. The only immortality available to us is the memory of future generations.

53 See: B. Shallcross, “Zbigniewa Herberta podróż do zachwytu," Teksty Drugie 2000, no. 3, p. 61. These epiphanies are also reminiscent of Nietzsche's idea of Augenblick.

${ }_{54}$ This term alludes to the platonic theory of ideas and the material world as a shadow of true being, but I will refrain from developing these ideas here.

${ }^{55}$ Józef Tischner developed the insight that beauty does not have any salvific potential, thus accentuating the difference between Greek philosophy and Christianity, which professes salvation through goodness. See: J. Tischner, Myślenie w żywiole piękna, ed. W. Bonowicz, Kraków 2005. Carlo Martini put forward similar arguments, but in slightly different terms; he believes that beauty can save the world, but it is not the beauty of art but of God and His Gospel. See: C.M. Martini, "Jakie piękno zbawi świat?," trans. Z. Zwolska, Ethos 2000, no. 4, pp. 19-35.

${ }^{56}$ The poem has a number of additional meanings related both to Herbert's ironic attitude to other poets and to his own poetic oeuvre.

${ }^{57}$ Gerard ter Borch also believed that the artist's task is to preserve the beautiful appearance of things. According to Herbert, this amounts to arresting (immortalising) a given instant of time. See: P. Siemaszko, op. cit., p. 178. 
This idea goes all the way back to the days of classical antiquity; as we know from Greek myths, Achilles chose a short life, radiant with fame, instead of a long, but utterly unremarkable, one. But this kind of immortality is at best vicarious (only the name, works, and deeds have the power to last) as well as being elitist (few can hope to be remembered after death). Herbert seems to share this point of view, suggesting that among the $20^{\text {th }}$-century poets, only Rilke, T.S. Eliot, and "a few other worthy shamans" will continue to be worshipped in the pantheon of the immortals ("To Ryszard Krynicki - A Letter"). Far more tragically, nameless victims of violence perish forever in an abyss of history ("Grandmother"). ${ }^{58}$ Unlike Czesław Miłosz, who was willing to believe that humanity will be saved through the art of forgetting (the conversation of the dead should be left to the dead), Herbert almost obsessively reiterated that it is our duty to cultivate the memory of those who were murdered. ${ }^{59}$

The fallen are still present ${ }^{60}-$ both in the things that have outlived them ("Buttons"), ${ }^{61}$ and in their heroic deeds. But, since history books are silent, preserving their memory becomes a moral obligation of every survivor ("Three Poems by Heart," "Wolves," "Mr. Cogito on the Need for Precision"). ${ }^{62}$ The murdered are asking us for "water of memories" ("Forest of Arden"), "a hillock of friable earth/ a slight sign from above" ("Warsaw Cemetery"). Unlike Cain, we have to become "our brothers' keepers" ("Mr. Cogito on the Need for Precision"), since their blood is crying out just like Abel's blood. Our memory of them is not just an act of covenant with them ${ }^{63}$ but also a victory over death; even if this does not mean resurrection, it saves their names from being erased from the book of history. After all, according to "Report from a Besieged City," it takes just one man who remembers to save the past. Even if it is hard to ascertain the names and the number of victims ("eyewitnesses (...) are inclined to exaggerate," "the official data/ diminish their number," while historians use "the disgraceful/ little word - 'approximately,") in these matters precision is essential; "one can't get it wrong/ even in a single case" ("Mr Cogito on the Need for Precision”).

58 The poem is devoted to Herbert's Armenian grandmother, who remembered the genocide of Armenians at the hands of Turks.

59 See: Z. Najder, “Ojczyzna i naród w poezji Zbigniewa Herberta," Ethos 2000, no. 4, pp. $141,144$.

60 'They left their trace, 'did not wholly die,' they are everywhere. Their whisper is heard every day. The whisper is terrifying." J. Kornhauser, op. cit., p. 25.

${ }^{61}$ Sometimes buttons are the only trace left of the victims, and thus they become symbols of our memory of them. The buttons in the poem "Farewell to September" have a very different significance; they mock Marshal Rydz-Śmigły's famous words that, in the event of war, Poland will concede a single button to the enemy.

${ }^{62}$ See: Z. Najder, op. cit., p. 141.

${ }^{63}$ See: E. Hirsch, "Chlust zimnej wody," trans. M. Heydel [in:] Poeci czytaja Herberta, op. cit., pp. 106-107. 
Our relations with the dead are further complicated by the fact that they still seem to look after us: "admonishing us in dreams/ returning our lost money/ trying to finagle us jobs/ mumbling lottery numbers" ("What Our Dead Do"). At times they are closer to us than the living, they comfort us, and they avoid conflict. They also play the role of a judging conscience; that is why, though we are hardly holy, we do our best to keep pace with them; if they disappeared, we would fall "into the pit/ of loneliness" ("Mr. Cogito on a Set Topic: "Friends Depart"). The dead may sometimes rebuke us, for instance for spending too much money on them; it would be better if, instead of buying expensive coffins, gravestones or wreaths, we gave the money to the poor ("What Our Dead Do"). This means that the roles have been reversed - rather than us remembering them, they remember us, and become our guardian spirits. Thus, the immortality in memory is paradoxical, as the living have a greater need for care from the dead than the other way around. But as we remain confined to the narrowly understood realm of empirical reason, we fail to discern the signs used by the dead to communicate with us. We fail to recognize their "tapping fingers on the pane" as a voice from the other side, mistaking it for the sound of a lost insect or a leaf. Blind to such signs, we "invent them an immortality/ snug as a mouse's burrow" ("What Our Dead Do"). Moreover, we hide our heroes under a stone slab, even though it subsequently turns into an instrument of isolation rather than a sign of memory ("Warsaw Cemetery"). Consequently, we revert to the rites of primitive peoples who, acting out of fear, wanted to prevent the dead from returning to the world of the living.

This does not mean that we deliberately chase the dead away from the world, but we are reluctant to lose control over them, and that is why we allocate them to various places, depending on our interests. In this way, the dead are objectified, reduced to the function of mediators and witnesses to our feuds, like helpless and expendable ghosts "who always turn up for an appointed meeting" ("In memoriam Nagy László”). In this way, Herbert illustrates Jean Paul Sartre's famous statement that death is an act of radical objectification of man, since it renders him utterly defenseless, at the mercy of the living. We do not remember the dead as they really were, but as we would like to see them now. If this is so, immortality in the memory of future generations is also illusive the more intrusive our inroads into the past, the more occluded it becomes under consecutive layers of oblivion. ${ }^{64}$ Likewise, attempts at appropriating the dead renders them, in a manner of speaking, even more dead, just like words which lose their meaning once they are made to serve a machinery of lies. ${ }^{65}$

This has brought us to the question of the death of language, as depicted by Herbert in a brief passage of lyrical prose entitled "Episode in a Library." Its subject is a sorrowful dirge of a fallen poet who has been reduced to "a salamander

${ }^{64}$ See: J. Kornhauser, op. cit., p. 25.

${ }^{65}$ See: K. Dybciak, op. cit., p. 147. 
gnawed by ants." As long as he was alive, the poet could delude himself that one day he would be resurrected in the words of his poetry, but an analysis of his work conducted with the aid of lines and dots, whose aim is not to hear the poet's cry but to find rhythms, accents, and caesuras, may imply that there is no limit to the process of the disintegration of culture (just like there is no end to the process of bodily decomposition in the grave). It may be true that during great crises (such as world wars or genocidal revolutions), one might think that humanity has reached the very nadir, but the future goes on to show that wars can become even more ruthless, and genocide even more viciously murderous. At the same time, the above-mentioned text is not limited to lambasting a given methodology and its focus on the formal structures of poetry, nor does it engage itself solely with delineating a crisis of values symptomatic of a given historical period. It also paints a picture of language death, caused by a rupture in the continuity of experience. This means that the words used by previous generations are hardly words at all to us, and that is why the fallen poet cannot live on in his work. ${ }^{66}$ To be sure, it is not impossible to interpret "Episode in a Library" in a more optimistic fashion (an accent here or a letter there will escape total annihilation ${ }^{67}$ ), but it is difficult to reassemble dots and lines into a meaningful whole, let alone detect in it the lamentation of the fallen poet. ${ }^{68}$

The belief in earthly immortality turns out to be every bit as naïve and misguided as belief in paradise. On the one hand, the atoms of our bodies will be irretrievably dispersed in the immensities of the universe, and on the other, our names, achievements (and words) will be forever forgotten by the generations to come. The poet's message is a pessimistic one; yes, our very existence in this world is nothing short of miraculous, but we are not going to be here forever. This implies that - according to the good counsels of Marcus Aurelius, one of Herbert's beloved thinkers - we should resign ourselves both to the impending termination of our existence and to being forgotten forever. ${ }^{69}$ This conclusion indicates that of the two ways only the way down is real; consequently, human life turns out to be an expedition for "the golden fleece

${ }^{66}$ See: B. Maj, "Mój prywatny epizod" [in:] Poeci czytają Herberta, op. cit., p. 53.

67 See: A. Franaszek, "Introduction" [in:] Poeci czytaja Herberta, op. cit., p. 7.

${ }^{68}$ Herbert himself also seems to share the pessimism: "What will remain after us are fragments of words scattered on the black earth. Accent signs over nothingness and ash" ("Episode in a Library"). In passing I would like to note that these words echo the famous last line of Pieśń by Tadeusz Borowski: "We'll leave behind us iron scrap/ and the hollow, mocking laugh of generations."

69 See: Marcus Aurelius, Meditations, trans. G. Hays, New York 2002: "This, too, you should always remember, that in a very short time both you and he must die; and, a little after, not even the name of either shall remain." (IV, 6) "All things are transitory, and, as it were, but for a day; both those who remember; and the things, and persons remembered." (IV, 35) "Soon you'll be ashes, or bones. A mere name, at most—and even that is just a sound, an echo." (V, 56) 
of nothingness." ${ }^{70}$ It is no accident that Gilgamesh appears in "The Envoy of Mr. Cogito" alongside Hector and Roland; having overcome innumerable obstacles, this mythical hero finds the plant of immortality only to lose it almost at once. Although now we can no longer hope for eternal life, there is no need to curse our fate; bearing in mind earthly disappointments and agonies, death may actually bring relief ("Stake").

\section{Anxiety and Anguish}

The picture is not yet complete; some have chosen the way up and others the way down, but there are also those who are incapable of committing themselves to either. Although nobody who has embarked on the way up or down can know with certainty whether they have made the right decision, they can still trust that they will be rewarded in proportion to their expectations. The undecided, those who cannot make a choice, become tired of uncertainty. Irrespective of who has made the correct choice, whether those who place their hopes in heaven or those who crave ultimate annihilation, both "will be reconciled by nothingness/ or mercy," but the sceptics, those who "received a baptism of earth," are condemned to the anguish of doubt ("Baptism"). Being neither ardent believers nor keen blasphemers, the fate which awaits them is the state of horrible suspension between nothingness and heaven.

There is little doubt that Herbert had a lot of sympathy for sceptics; this is borne out not only by the emotional tone of the poem "Baptism" but also by the figure of Mr. Cogito himself. In spite of his Cartesian roots, Mr. Cogito is no thought experiment devised to overcome doubt by uncovering the absolute foundation of knowledge. On the contrary, the amiable protagonist (whose credulity occasionally arouses our pity) on closer inspection turns out to be Mr. Dubito, unable to overcome his scepticism. He is more akin to the sages of antiquity than to modern-day philosophers, with their search for absolute certainty. He is aware of the equivalence of all judgments, which renders him

${ }^{70}$ Marek Adamiec in his book '...Pomnik trochę niezupetny... 'Rzecz o apokryfach i poezji Zbigniewa Herberta (Gdańsk 1996) argues that Herbert was an apologist of nothingness, while his poetry is a voice of despair. On the one hand, such a radical conclusion is hard to accept for a number of reasons, one of them being the complexity and antinomianism of Herbert's work. On the other and, one cannot dismiss it out of hand; this is why Agnieszka Bielak's review of the book Interpretacje i dowolności (Ethos 2000, no. 4, pp. 223-226) errs on the side of harshness. Przemysław Czapliński in his article "Śmierć, czyli o niedoskonałości" argues that for Herbert death was a doorway to nothingness, every bit as absurd as life; it is so because in Herbert's world one lives and dies without reason. See: W. Pyczek, "Próby poznawania Herberta," Ethos 2000, no. 4, p. 214. 
incapable of choosing either yes or no. ${ }^{71}$ Heedless of Jesus' explicit words of warning, ${ }^{72} \mathrm{Mr}$. Cogito is at times ready to assume that the truth is neither "yes" nor "no," while on other occasions it can be both at once. Unlike his philosophical progenitor, Herbert's hero is constantly in motion, incidentally, just like his creator. After all, Zbigniew Herbert was not an imperious lecturing preacher but a questing poet ${ }^{73}$ grappling with the complexities of the world and human affairs.

One instance of this attitude is his inner voice, which has nothing to argue for and nothing to warn against ("Inner Voice"); thus, it seems even more enigmatic than the daimonion of Socrates, which may have never told the Greek philosopher what to do but could always be trusted to warn him clearly against all evil. The voice of the Philosopher was an absolute imperative which could not be defied. The inner voice of Mr. Cogito, by contrast, is small and diffident, and that is why it can be easily ignored or even suppressed; all the more so as, instead of proposing viable solutions, it is busy multiplying new questions and quandaries. But this state of uncertainty is the very essence of human grandeur and the glory of human existence ("Nike Who Hesitates"). ${ }^{74}$ After all, the message of Herbert's play Cave of Philosophers reminds us that truth remains hidden; in the same way as none of Socrates' disciples managed to find the secret of their master's personality (while their descriptions of it contradict one another) no sage can solve the mystery of the universe ("Mr. Cogito and Pop")..$^{75}$ The last word of humankind turns out to be incertitude and doubt; although both are difficult states to be in, they are also the fullest expressions of our nature. ${ }^{76}$

Herbert's sympathy for scepticism is also evident in the poem "Thomas," which recounts the story of the apostle who did not believe in Jesus' resurrection.

${ }^{71}$ See: S. Barańczak, op. cit., pp. 30, 77.

72 See: 'All you need to say is simply 'Yes' or 'No'; anything beyond this comes from the evil one" (Mt 5, 37).

73 See: W. Kruszewski, "Autorytet poetycki Zbigniewa Herberta," Ethos 2000, no. 4, pp. 210-211.

${ }^{74}$ The poem is also rich in other meanings, several of which can only be mentioned in passing here; what is indubitable, however, is that the poem also shows the correctness of a sceptical vantage point. After all, Nike was a vengeful and chauvinist goddess of victory; when hesitating, she becomes a goddess of reflection, perhaps even of compassion for the defeated. See: A. Zagajewski, op. cit., p. 170.

75 See: M.K. Siwiec, "Zbigniew Herbert - ku tajemnicy Sokratesa," Filo-Sofija 2012, no. 2, p. 18. Herbert showed a similar scepticism towards archeological research; on the one hand, he argued that, like any other science, archeology deals solely in hypotheses (which can be countered with solid arguments), on the other, he stressed that we know too much about sugarcoating lies of art to trust even the source materials. See: Z. Herbert, Labirynt nad morzem, op. cit., pp. 40,72 .

${ }^{76}$ See: J. Hartwig, "Herbert, który się waha" [in:] Poeci czytają Herberta, op. cit., pp. 120 121. In Herbert's opinion, only the knocker is free from ambiguity. See: ibid. 
It is true that he stopped hesitating after being rebuked by the master, but the scene itself seems to indicate that truth can come to us only as unmediated revelation of the divine. Only God can remove all ambiguities, for instance by proving that the resurrected Jesus is not a figment of the imagination but the teacher himself, who has risen from the dead. Nonetheless, if man were to embrace such a revelation, he would have to be not the doubt-ridden Mr. Cogito, but rather the doubt-resistant Mr. Credo. ${ }^{77}$ But to dispel all doubt and commit oneself to either yes or no may lead to persecution; innumerable men of faith have been thrown into prison or burnt at the stake for their beliefs. Perhaps this is why Mr. Cogito hopes that God does not condemn sceptics and disbelievers, because He understands the limitations of our cognitive powers: "so doubt is permitted/ we are free to question/ so Leonardo da Vinci's/ furrowed forehead/ has value after all" ("Thomas"). The poem "Homily" carries a similar message; the speaker argues that those who doubt (or even disobey) are also "God's little ones"; it is even possible that they are the ones who are genuinely looking for God, in contrast to unbelievers (who deny God's existence) and believers (who have already found Him).

Incertitude in the realm of ultimate things (such as the existence of God or eternal life) does not make Herbert into an out-and-out sceptic, always negating everything. On the contrary, his poetry is ample evidence that, on the one hand, his scepticism was always accompanied by irony, while on the other, it shows that he always drew the line at the most fundamental and inviolable moral values which must never be called into question. Where the fate of the most vulnerable is at stake, there is little room for vacillation or pleas of ignorance; that is why Mr. Cogito adores tautology ("Mr. Cogito and the Imagination"). ${ }^{78}$ It must be stressed that scepticism has nothing to do with moral relativism; nor does it give consent to settling disputes by force. On the contrary, scepticism is a voice of caution; bearing in mind that we are never free from the risk of error, we should not impose our point of view on others. At the same time, scepticism is a safeguard against the actions of ornament-makers

77 This figure appears in the poetry of Father Alfred Marek Wierzbicki (Fotografia rodzinna, Lublin 2010; and: 76 wierszy, 2017). While Mr. Credo remains open to the voice of God, Mr. Cogito is more of a Janus-like individual, with his twin faces turned in two opposite directions. See: S. Barańczak, op. cit., p. 31.

${ }^{78}$ Changing the meanings of words is particularly dangerous (calling falsehood or lie the truth). See: E. Hirsch, op. cit., p. 105. Without going into too much detail, it should be noted that the way in which Herbert understood and employed the notion of tautology in his poetry far exceeds the technical sense of the term as used in formal logic. One ought to note that a culture deprived of fundamental and universally accepted notions regarded as self-evidently true (in other words, "tautologies") in all probability could not survive. This conclusion also implies that the great crises of culture are caused by their abandonment of tautology, in particular by tinkering with its meaning, for instance when democracy comes to be defined as "the dictatorship of the proletariat," liberty as chaos or anarchy, and human rights as a conspiracy of the elites or specific groups of interest. 
who want to replace reality with fiction. This conclusion indicates that $\mathrm{Mr}$. Cogito, who remains suspended between doubt and faith, is a tragic figure, sentenced to everlasting (perhaps even unhuman) wavering between choosing the way up or the way down. ${ }^{79}$

Translated by Przemystaw Michalski

\section{Bibliography}

Adamiec M., '...Pomnik trochę niezupetny...' Rzecz o apokryfach i poezji Zbigniewa Herberta, Gdańsk 1996.

Barańczak S., A Fugitive from Utopia: The Poetry of Zbigniew Herbert, Cambridge (Massachusetts) 1987.

Barańczak S., Uciekinier z Utopii. O poezji Zbigniewa Herberta, Londyn 1984.

Bielak A., "Interpretacje i dowolności," Ethos 2000, no. 4.

Bonowicz W., "Otwarcie wiersza" [in:] Poeci czytaja Herberta, ed. A. Franaszek, Kraków 2009.

Borges J.L., "Nieśmiertelność," trans. D. Walasek-Elbanowska, Literatura na Świecie 1988, no. 12.

Borges J.L., "Nieśmiertelny," trans. M. Potok-Nycz [in:] idem, Alef, trans. Z. Chądzyńska, M. Potok-Nycz, Warszawa 2003.

Borges J.L., "Pamiętliwy Funes" [in:] idem, Fikcje, trans. A. Sobol-Jurczykowski, S. Zembrzuski, Warszawa 2003.

Brandstaetter R., Bardzo krótkie i nieco dtuższe opowieści, Poznań 1984.

Cyranowicz M., "Herbertowskie inedita," Ethos 2000, no. 4.

Czapliński P., "Śmierć, czyli o niedoskonałości" [in:] Poznawanie Herberta, ed. A. Franaszek, Kraków 1998.

Dybciak K., Gry i katastrofy, Warszawa 1980.

Dzień M., "Bogowie Herberta," Teksty Drugie 2000, no. 3.

Garbol T., "Kilka czystych taktów," Ethos 2000, no. 4.

Gutorow J., "Herbert, pies i gwiazda" [in:] Poeci czytaja Herberta, ed. A. Franaszek, Kraków 2009.

Hartwig J., "Herbert, który się waha” [in:] Poeci czytają Herberta, ed. A. Franaszek, Kraków 2009.

Herbert Z., The Collected Poems 1956-1998, trans. A. Valles, London 2014.

79 According to Sochoń, Epilogue to a Storm proves that Herbert overcame doubt and discovered a sense of unity with the Creator of Everything. See: J. Sochoń, op. cit., p. 113. Mateusz Werner, by contrast, is convinced that Herbert was a frustrated poet, who elevated himself to the status of inerrant authority and judge. See: W. Pyczek, op. cit., p. 213. Both assessments seem lopsided; if viewed through the prism of Mr. Cogito, Herbert was more of a tragic (post) Cartesian. See: E. Hirsch, op. cit., p. 105. 
Herbert Z., The Collected Prose, 1948-1998, ed. A. Valles, trans. M. March, J. Anders, B. Carpenter, A. Valles, New York 2010.

Hirsch E., "Chlust zimnej wody," trans. M. Heydel [in:] Poeci czytają Herberta, ed. A. Franaszek, Kraków 2009.

Höffe O., Immanuel Kant, trans. A.M. Kaniowski, Warszawa 2003.

Kijas Z., Niebo, czyściec, piekto. W domu Ojca, dla kogo, w oddaleniu, Kraków 2010. Kopciński J., Nastuchiwanie. Sztuki na gtosy Zbigniewa Herberta, Warszawa 2008.

Kornhauser J., “'Struna światła' - między ocaleniem a niepokojem,” Teksty Drugie 2000, no. 3 .

Kruszewski W., “Autorytet poetycki Zbigniewa Herberta," Ethos 2000, no. 4.

Maj B., "Mój prywatny epizod" [in:] Poeci czytaja Herberta, ed. A. Franaszek, Kraków 2009.

Marcus Aurelius, Meditations, trans. Gregory Hays, New York 2002.

Martini C., "Jakie piękno zbawi świat?," trans. Z. Zwolska, Ethos 2000, no. 4.

Montaigne M. de, The Complete Essays, trans. D.M. Frame, Pal Alto 1958.

Najder Z., "Ojczyzna i naród w poezji Zbigniewa Herberta," Ethos 2000, no. 4.

Nycz R., “'Niepewna jasność' tekstu i 'wierność interpretacji.' Wokół wiersza Zbigniewa Herberta 'Pan Cogito opowiada o kuszeniu Spinozy,'” Teksty Drugie 2000, no. 3 .

Puzynina J., "Niebo Herberta," Ethos 2000, no. 4.

Pyczek W., "Próby poznawania Herberta," Ethos 2000, no. 4.

Sady W., Dzieje religii, filozofii i nauki. Od Pico della Mirandoli do Miguela Serveta, Kęty 2013.

Shallcross B., "Zbigniewa Herberta podróż do zachwytu," Teksty Drugie 2000, no. 3 .

Siemaszko P., "Piękno jako odpowiedź. O malarskich fascynacjach Herberta," Ethos 2000, no. 4.

Siwiec M.K., “Zbigniew Herbert - ku tajemnicy Sokratesa,” Filo-Sofija 2012, no. 2.

Siwiec M.K., "Zbigniew Herbert - twórca i źródło. Droga do źródła i źródło w wierszu 'Ścieżka,'” Filo-Sofija 2013, no. 3.

Sochoń J., “Bóg poety," Ethos 2000, no. 4.

Sosnowski A., "Epizod” [in:] Poeci czytają Herberta, ed. A. Franaszek, Kraków 2009.

Szram M., Ciato zmartwychwstate w myśli patrystycznej przetomu II i III wieku, Lublin 2010.

Tischner J., Myślenie w żywiole piękna, ed. W. Bonowicz, Kraków 2005.

Tischner Ł., Gombrowicza milczenie o Bogu, Kraków 2013.

Tischner Ł., Sekrety manichejskich trucizn. Mitosz wobec zta, Kraków 2001.

Wierzbicki A.M., 76 wierszy, Lublin 2017.

Wierzbicki A.M., Fotografia rodzinna, Lublin 2010.

Williams B., "The Macropulos Case: Reflections on the Tedium of Immortality" [in:] Problems of the Self: Philosophical Papers 1956-1972, Cambridge 1973.

Zagajewski A., "Niejasne przesłanie" [in:] Poeci czytają Herberta, ed. A. Franaszek, Kraków 2009. 